\title{
CHANGING PATTERN OF CORPORATE GOVERNANCE AND FINANCING IN THE KOREAN CHAEBOLS
}

by

\author{
BYUNG S. MIN*
}

The de jure financial system in Korea has moved from mainly $R$ (relationship)mode financial contracts towards M (market)-mode contracts since the 1997 financial crisis, due largely to reforms introducing Anglo-American style corporate governance and the disintermediation of the larger business groups in corporate financing. Analysis shows that the effectiveness of this change in improving firms' performances has yet to be demonstrated. Unlike the disintermediation of the big-name firms, the affiliates of small and medium business groups and small and medium-sized independent firms have relied heavily on bank loans and internal finance. The impact of a more concentrated banking system and intensified competition on the type of corporate investment has yet to be analysed.

JEL Codes: G34, O53

Key Words: Business groups, corporate governance, Korea

\section{Introduction}

How to prevent possible managerial misconduct and improve performance through proper monitoring, auditing and control has been one of the crucial issues since the 1997 Asian financial crisis (see the special issues of the Journal of Financial Economics, 2003, Vol. 69, No. 1; and the Journal of Financial and Quantitative Analysis, 2003, Vol. 38 , No. 1). Increased vulnerability to external shocks resulting from poor governance in both the corporate and financial sectors was one of the causes of the crisis (Mitton, 2002, Johnson et al. 2000, among others). The failure of corporate monitoring and control led to managerial problems, whereby excessive levels of inefficient investment and a vulnerable financial structure were perpetuated (Borensztein and Lee, 1999; Corsetti et al., 1999). The 1997 Asian crisis and the resulting economic crisis clearly demonstrated that the role of the financial market is crucial for corporate governance, which in turn is an essential ingredient for financial stability in emerging markets. ${ }^{1}$

Griffith Business School, Griffith University, Brisbane, Queensland, Australia. I thank the joint editor (Russell Smyth) and the referee for helpful comments. The usual disclaimer applies.

1 The issue of governance is not necessarily confined to emerging markets. The Enron scandal in 2001 in the U.S. and the collapse of OneTel in Australia are other prime examples of the adverse effects of a poor governance system. Therefore, the system of governance is a critical feature in the longer-term performance of an economy. In order to address such problems and reduce the risk of future corporate governance failures, much work is underway, both globally and at the domestic level. The OECD has produced a set of corporate governance principles that have become the basic template for assessing 
The corporate governance issue has also become one of the most popular research topics among scholars of the South Korean (hereafter the Korean) economy. The major issues covered by this research include: (1) the role of government in reforming chaebol (business group) and corporate governance (Haggard et al., 2003; Joh, 2001; Yoo, 1999); (2) reform of bankruptcy procedures and firm exits (Lim, 2003; Nam and Oh, 2000); (3) protection of minority shareholders' rights and the role of outside directors (Lee, 1996; Black et al., 2003); (4) governance structure of corporate bonds (Rhee et al. 2003; Lim, 2004); and (5) governance and ownership of banks (Choe and Lee, 2003; Park, 1997). Having noted that the governance of both the corporate sector and the banking sector was distorted and functioning ineffectively before the crisis, there has been a good deal of discussion as to the required reforms and institutional rearrangements since the crisis occurred.

The existing literature, however, focuses mainly on the issue of 'internal' governance from an institutional perspective. In contrast, this paper will analyse the issue of 'external' governance in the context of corporate finance. ${ }^{2}$ External corporate governance in this paper refers to the process by which investors monitor and control the actions of corporate management to assure themselves of obtaining a return on their investment (Schleifer and Vishny, 1997). One of the lessons of the 1997 financial crisis has been a renewed recognition of the importance of links between the corporate and financial sectors, both theoretically and empirically (Kaminsky and Reinhart, 1999; Claessens, 2003). Furthermore, the relationship between chaebols and financial intermediaries has changed since the 1997 crisis because of sweeping reforms and changes to corporate financing.

One interesting question relates to the relationship between business groups and financial intermediaries from a dynamic perspective. What factors were most critical to the advent of chaebols and what are the major challenges they have faced since the 1997 crisis? Has the focus of corporate governance shifted from bank-oriented towards more (capital) market-oriented governance? If there has been change, what factors led to this shift? What factors need to be considered for the governance mechanism to be effective in improving efficiency and profitability?

The Korean economy provides an interesting case study because it experienced significant change both before and after the 1997 crisis. The following section describes the bank-business group relationship before the crisis. The present section investigates the formation of business groups and their contribution to the economy, as well as their legacies in the context of bank financing. Section 3 analyses the relationship after the crisis. In particular, it compares the impact of the crisis on the major business groups with that on small-to-medium sized groups. Having noted that the choice of financial

countries' corporate governance arrangements. This set of principles involves a number of elements that include a clear understanding by directors of their company's strategic objectives, systems to ensure the effective management of risks, and mechanisms to ensure that the company's obligations are identified and discharged as part of the social and economic system. Like the OECD, the Basel Committee on Banking Supervision is responsible for establishing international banking supervision principles. Banks are required to meet a BIS $8 \%$ equity ratio in Korea.

2 The issue of corporate governance involves many systems and structures, both inside and outside the firm. The internal governance mechanism includes the role of the director and the board, ownership structure, outside directors, and shareholders, including minority shareholders. A core part of this internal structure is to ensure that the board of directors practises sound business ethics (Cremers et al., 2005; Denis and McConnell, 2003). The primary external corporate governance mechanisms include: (1) the legal system; and (2) the external market for corporate control. 
contracts is dynamic rather than fixed, Section 4 investigates factors that need to be considered to enhance efficiency and profitability in the current context. The final section provides a summary and conclusions.

\section{The Bank-Business Group Relationship before the Financial Crisis}

\subsection{Policy Loans, Ownership Protection and the Advent of Chaebols}

Indirect financing through the banks was most popular before the financial crisis, particularly when authoritarian governments pursued a 'compressed-growth' policy. Collateral value was a determining factor for access to credit market in Korea, given the lenders' poor knowledge of risk assessment techniques. This resulted in the creation of a dual industry structure, whereby there was disproportionately more growth in the average size of existing establishments (i.e. chaebols) than in the number of new establishments in industries dependent on external finance. The number of subsidiaries of the thirty largest chaebols grew from 126 in 1970 to 429 in 1979 (Yoo, 1999).

From the 1960s, the Korean Government encouraged a debt-financed growth policy. Debt financing without recourse to the public was politically expedient. The level of development of the capital market was also poor. In particular, the Government intervened heavily in the commercial banks' credit allocation during the 1970s, when the so-called 'big-push' industry policy and export-driven growth were under way. The 'big-push' policy focused on selected heavy and chemical industries (HCIs). ${ }^{3}$ The banks did not evaluate whether borrowers could pay back their loans because of the fact that the Government directed bank lending and injected capital when necessary in order to support financially distressed debtors.

While the banks were privatised in 1981-1983, the Government influenced credit allocation through its continued appointment of bank CEOs until 1993. It also continued to approve bank CEO appointments until political democratisation began in 1997. Top bank managers often had short-term appointments (around three years), which meant that they only needed to prop up failing firms for a few years in order to avoid loan defaults during their tenure (Chiu and Joh, 2003). The Government also guaranteed payment to foreign creditors because of the poor reputation of domestic firms in the global market.

In addition to creditors' diminished incentive to monitor borrowers, business groups often exploited their superior bargaining power in relation to lenders to protect managerial control. In contrast to the failing small firms that exited the market, large chaebols facing financial distress received subsidised loans and capital injections through the banks (1972 debt crisis; 1979- 1983 depression; 1984- 1988 business insolvencies), which reinforced-in some chaebol chairmen-a deeply-rooted belief in the myth of too-big-to-fail (Yoo, 1999; Joh, 2001). The rescue packages for financially stressed banks in the process of supporting large firms led entrepreneurs to pursue quantity-based expansion strategies. Besides fuelling economic growth, these loans helped such firms to accumulate capital, expand into other industries, and develop longterm banking and political relationships (Graham, 2003). Even when the Government did not bail out distressed firms, governmental supervision and bankruptcy proceedings aggravated moral hazard (Chiu and Joh, 2003). Firms successfully lobbied the

3 The share of HCIs in GDP was $11.9 \%$ in $1970,26.3 \%$ in 1980 , and $31.3 \%$ in 1988 . 
Government's Bank Supervisory Board (formerly the Financial Supervisory Commission) for favourable treatment from banks.

Ownership protection, coupled with poorly set out accounting disclosure requirements, strengthened entrepreneurs' managerial control. As part of the incentives for entrepreneurs to participate in the development strategy, the Government also protected ownership by restricting mergers and acquisitions (M\&As) and mandatory 'tender offer' law. ${ }^{4}$ Naturally, foreign direct investment was discouraged. This ownership of firms has diffused since affiliations have been publicised, particularly the holdings of the chairmen (and their families). Currently, few block shareholders own more than $5 \%$ of shares. However, the chairmen's control has not been diluted. This is because of the circular patterns of interlocking shareholdings among affiliates. A chairman can effectively control the whole group as long as he controls the core company at the centre of the interlocking process. ${ }^{5}$

The chaebols' affliates had relatively better access than independent firms to the credit market by reason of the superior collateral power generated by mutual debt payment. In theory, the interlocking shareholdings or equity ownerships could encourage efficient action in settings in which firms were concerned with expropriation and hold up problems arising from relationship-specific investments (Fee, Hadlock and Thomas, 2006). The loan policies and complicated structures of chaebols may have contributed to overcoming the coordination failures in the capital market in the early stages of development (Shin and Park, 1999). Berle- Meansian scholars argue that an owner- manager company can reduce agency costs because corporate governance is more effective (Huddart, 1993; Himmerlberg et al., 1999).

However, as described in Section 2.2.2, the Korean experience indicates that the problems of policy loans and chaebols in general have become more acute as the economy has developed. The role of creditors was crucial to monitoring and controlling debtors but the creditors' corporate governance was greatly restricted by 'crony capitalism'. Furthermore, the chaebols levered their bargaining power against the creditors' control.

\subsection{The Advantages and Disadvantages of Chaebols}

\subsubsection{Advantages and Contribution to the Economy}

Business groups have led Korean economic growth, and the role of the chaebols in the Korean economy has been significant. The top thirty chaebols accounted for $40.2 \%$ of the value added in the industrial sector in 1995 and more than $60 \%$ of Korean firms subject to external audit belong to business groups (Joh, 2001). A chaebols investment vis-à-vis that of a non-chaebol firm has been significantly related to growth

The Korean law required anyone acquiring $25 \%$ of a firm's shares to tender an offer for at least $50 \%$ of its shares. As a result, plural-ownership takeovers were effectively prevented.

5 The chairman can control all members in a group of companies if he controls the core company of the group. This is due to interlocking ownership among subsidiaries. Chaebol-affiliated firms often use 'circular' patterns of institutional ownership because (direct) mutual interlocking ownership is disallowed. For example, Company 1 (the core company of A Group) holds shares in Affiliate 2 which in turn holds Affiliate 3, which in turn holds shares issued by Company 1. Given this interlocking system, the chairman effectively controls all group member companies if s/he controls the core company. Despite the existence of several de facto holding companies, the establishment of holding companies was not allowed until 1998. 
opportunities (Shin and Park, 1999). Despite some uncertainty, the charisma of the chaebols' founder-managers helped them to invest in projects from a long-term perspective rather than based on a myopic strategy that would appeal to shareholders.

Business groups have also led Korean exports through the creation of global brands and competitiveness. The top five export items including shipbuilding and motor vehicles are largely from the heavy and chemical industries (HCIs) produced by chaebols. Samsung has become a world leader in several key manufacturing industries such as memory-chips, flat-panel monitors (the absolute leader), DVD players (the second) and cellular phones (the third) (Fortune, 2005). The brand value of Samsung is estimated at $\$ 16.2$ billion U.S. (world ranking $20^{\text {th }}$ in 2006). Other chaebols such as Hyundai Motor Co. (global brand value ranking $84^{\text {th }}$ in 2006) and LG Electronics (global brand value ranking $94^{\text {th }}$ in 2006) have also become among the world's best known producers of automobiles, air conditioners, and CD-ROM drives (Business Week, 2004). Business groups have contributed to creating jobs domestically and establishing the brand image of Korea globally.

\subsubsection{Disadvantage of Economic Concentration}

On the other hand, highly concentrated economic power by the chaebols, coupled with Government regulation of the banking sector, nullified the corporate governance function of creditors and created a dualistic industry structure. As La Porta et al. (1998) indicated, the lack of strict enforcement of laws has proportionally disadvantaged small and medium-sized enterprises (SMEs) and non-export firms. ${ }^{6}$ Instead of increasing profitability, the chairmen of the chaebols created business empires, mainly through debt financing, for the purpose of inefficient horizontal diversification.

The debt-financing policy, coupled with the rapid growth of the banking system following interest rate reform in 1965 , led to the soaring debt- equity ratio of firms in the industrial sector from around $100 \%$ in the early 1960 s to around $500 \%$ in mid 1980 s. $^{7}$ Meanwhile, the Government introduced the principal transactions bank (PTB) system in the 1970s (Nam, 1996) as well as fiscal policies (National Federation of Economists, 1996) to improve corporate financial structure. Despite these regulatory measures, the debt- equity ratios of business groups remained high. The PTB system introduced in the 1970s failed to curb chaebols' rising debt- equity ratios. The PTB system mainly sought to control the thirty largest chaebols' financial structure at the macro-level. The medium-to-small chaebols (top six-to-thirty) increased their debtequity ratios significantly. These groups invested in and effectively controlled the money market by owning merchant banks and other non-bank financial institutions (NBFIs) including insurance and securities firms (Graham, 2003). The leverage (medians) during 1988 and 1996 was three times higher than in the U.S. and Germany, and nearly double that in most Asian countries (Claessens, 2003, Table 3).

La Porta et al. (1998) show that the index for creditors' rights for Korea (U.S.) was 3 (1) and for equity rights was 2 (5).

Other factors include the inadequacy of business savings in relation to investment needs and the biases in the tax systems that have favoured debt finance (Sundararajan, 1985). 
The high debt- equity ratio prolonged the investment boom before the financial crisis. Even during 1994- 1995, when exports were strong, the total borrowings of large corporations increased, indicating that they invested more than they earned. And they did not stop investing in 1996 when external conditions deteriorated. The average debt-equity ratio for manufacturing was conservatively estimated at $458 \%$ in 1997. Because of the liberalisation programme in the early 1990s, Korean corporations faced new domestic and foreign entrants. They increased their investment to upgrade and/or expand their production facilities to enhance their competitiveness in both domestic and global markets, particularly in the face of an expected U.S.-led recovery. The myth of too-big-to-fail was prevalent, and a sluggish stock market also contributed to the situation.

The crucial problem along with this sustained high debt-equity ratio was the poor profitability of the indebted chaebols and their excessive levels of inefficient investment (Borensztein and Lee, 1999; Corsetti et al. 1999; Joh, 2003). The average rate of return on equity was often lower than the prevailing interest rate for loans (particularly in the early 1980s and the 1990s) (Joh, 2003). As in other East Asian countries (Mitton, 2002; Johnson et al., 2000), Joh (2003) finds that when a business group transferred resources from one subsidiary to another, these resources were often wasted during 1993-1997. This suggests that a great disparity between managerial control and legal ownership can cause lower profitability, ${ }^{8}$ especially since the profitability of business group affiliates was lower than that of independent firms.

The Korean chaebols used equity shareholdings mainly to pursue horizontal diversification and secure bank loans. Corporate governance should be strengthened as the economy grows and the business environment for contracting changes. The incomplete contract theory implies that an entrepreneur cares about both pecuniary and non-pecuniary rewards from projects, while an investor is only concerned with monetary returns (Aghion and Bolton, 1992). This suggests that owner- manager firms - chaebols - have inherent incentives to seek an expansionary policy unless there is a proper governance mechanism. Entrepreneurs eventually seek private gain at the expense of other shareholders-a practice known as 'tunnelling' (Johnson et al., 2000; Shleifer and Vishny, 1997; Claessens et al., 2002; Lins, 2003). Lang and Stulz's (1994) evidence also shows that diversified firms have reduced their value in comparison to specialised firms (average firms in the same industry). Firms that expand mainly into similar activities can enhance their performance by sharing some of their existing skills and hence may have a comparative advantage in these activities.

Although ownership protection preserved the managerial control of entrepreneurs, ownership has gradually been de-concentrated in Korea as firms have increased in size, particularly after listing on the stock-exchange. Using a credit rating agency's data-set which comprised 5,829 firms during the period 1993- 1997, Joh (2003) has shown that ownership concentration of the top seventy large business group affiliated firms (17.12\%) was lower than that of independent firms $(29.2 \%)$ and the average of all firms $(45.19 \%)$. The data-set also shows that the ownership of the top seventy chaebols (by size) increased from $17.23 \%$ in 1993 to $18.64 \%$ in 1995 , but decreased thereafter to $15.37 \%$ in 1997 . However, Villalonga and Amit (2006) claim that ownership should be distinguished from control and management in the case of family firms. When controlling shareholders' control rights exceed their ownership rights they have an incentive to expropriate firm resources, as their private benefits exceed their costs. The chairman (chongsu) of a chaebol in Korea has often enjoyed more managerial control than ownership. 
In summary, the prevalence of crony capitalism created a danger for both lenders and borrowers, whereby the excessive level of inefficient diversification of the chaebols was uncontrolled. Long-term excess leverage and poor profitability made the indebted firms and the economy as a whole vulnerable to cyclical downturns in the global market. 


\subsection{Legacies of Bank-Financed Growth: Why the Crisis Happened in the Late 1990s and not Before}

An interesting question here is why the crisis happened in the late 1990s rather than the 1980s. The prevalence of high corporate debt- equity ratios is detrimental to macroeconomic stability (Sundararajan, 1985). When the leverage exceeds a critical limit, even the direction of the effect of financial policies is changed, and stabilisation policies involve very high costs in terms of growth foregone. However, high debtequity ratios were prevalent in the early 1980s without resulting in a crisis. Although the legacies of poor corporate governance were evident in both decades, the domestic and global economic situations in the 1990s differed from those in the previous decade in a number of significant respects.

First, speedy liberalisation in the 1990s without proper prudential regulation led to fierce competition among financial intermediaries. There was rapid liberalisation of the financial market, including capital market transactions, especially since 1993. Meanwhile, there were new entries to the market in the 1990s, including two commercial banks, and twenty-six investment finance companies (IFCs) were converted into merchant banks in 1994 and 1996 ( $\mathrm{Ra}$ and Yan, 2000). International capital mobility was virtually completely free by 1996 , when Korea became an OECD member. However, there was no proper implementation of prudential regulation for the banks until the onset of the crisis. There were mismatched assets and liabilities in both commercial and merchant banks. They obtained finance from the short-term market overseas to lend to corporations for long-term projects. But in the absence of capital control, the foreign lenders stopped rolling-over the lending when they observed snowballing, non-performing loans (NPLs) to domestic banks caused by a series of chaebol bankruptcies in the mid 1990s when a cyclical downturn of global business hit the Korean economy. In the process of political democratisation and preparation to join the OECD, the Government explicitly signalled that it no longer guaranteed payments made to foreign lenders and would not bail out lenders for capital injections to chaebols, which was naturally a 'cold shower' for foreign investors. The rolling over rate of foreign debts was almost $100 \%$ up until July 1997, when it started to drop, reaching $30 \%$ in December 1997. In consequence, the domestic banks also stopped roll-over lending to firms that were blocked from foreign financing. This created a vicious circle of corporate bankruptcies and accumulated NPLs for the banks. ${ }^{9}$

Internationally, financial contagion effects became greater as the global economy became more interconnected, either through bilateral trade (Imbs, 2006), the wealth effect of financial intermediaries (Kyle and Xiong, 2001), or both of these factors. Southeast Asia had emerged as the most important destination for Korea's exports. Its share of total exports increased from $16 \%$ in 1990 to $24.2 \%$ in 1994 . But the increased competition among financial intermediaries after 1993 drove merchant banks to be extreme risk takers when investing in Southeast Asia (Min, 1999; Ra et al., 2000). Thus, due to a lack of policy coordination, the degree of financial integration in East Asia was increased without a strong anchoring mechanism. When financial intermediaries suffer

The amounts of NPLs are controversial. Ji and Park (1999) estimated the NPLs increased from 3.9\% in 1996 to $14.9 \%$ in 1997 . He (2004) has shown that the ratio peaked in 1998 (16.8\%) and has dropped in the following years (12.9\% in $1999,8 \%$ in 2000 , and $2.3 \%$ in 2002). According to the Financial Supervisory Commission's press releases, $6.7 \%$ of all loans were non-performing loans by the end of 1997, and this was estimated to reach 10\% by June 1998. 
trading losses, they have a reduced capacity to bear risks, resulting in reduced market liquidity, increased price volatility in both markets, and increased correlation.

By contrast, in the 1980s there were no snow-balling NPLs in the banking sector, the Government's (implicit) payment guarantee eliminated the lending risk for foreign creditors; there were no severe adverse terms of trade shocks that affected Korea's major export items; the myth of too-big-to-fail was still prevalent; and massive capital flows across borders were restricted due to the controlled capital market. The degree of market integration in the 1980s in the Asian region was also weaker, both in terms of bilateral trade and financial transactions.

\section{The Bank-Business Group Relationship after the Crisis}

\subsection{Top Business Groups}

\subsubsection{The Crisis and Market Screening: Why Some Top Chaebols Collapsed}

After the onset of the crisis, the IMF provided bail-out funds subject to reforms and improvement of macroeconomic indicators. The sweeping reforms included the restructuring of chaebols and corporate governance (Haggard et al., 2003; Joh, 2001; Yoo, 1999); reforms in bankruptcy procedures and firm exit procedures (Lim, 2003; Nam and Oh, 2000); protection of minority shareholders' rights and the role of outside directors (Lee, 1996; Black et al. 2003); changes in the governance structure of corporate bond markets (Rhee et al. 2003; Lim, 2004); and reforms to the banking sector (Choe and Lee, 2003; Park 1997).

In particular, the Government mandated restructuring of the top five chaebols (1) to improve accounting disclosure arrangements such as the publishing of consolidated financial statements beginning in fiscal year 1999; (2) to eliminate mutual payment guarantees among subsidiaries of the top 30 chaebols by March 2000; (3) to reduce debt- equity ratios to $200 \%$ by the end of 1999 ; (4) to concentrate on core competencies via the so-called 'big deal'; (5) to appoint outside directors to the management boards of the chaebols and strengthen the rights of minority shareholders; and (6) (a year later) to prohibit interlocking share holdings among group members. The 'big-deal' required the swapping of firms/factories among the groups in order to force the groups to focus on core competent businesses (refer to Footnote 10).

Because of prolonged managerial inertia based on the myth of too-big-to-fail, the Daewoo group (ranked No. 3) collapsed and the Hyundai group (ranked No. 1 in terms of assets) was broken down into the Hyundai Motor Vehicle Co. and Hyundai group. Most chaebols had relied heavily on commercial paper (CP) and corporate bonds until the early 1990s. Unlike issuing bonds and shares, the issuers of CP can by-pass financial intermediaries to raise funds in the direct CP market. Regulation of access to bank finance by the top thirty chaebols has gradually been tightened. Since CP are high-risk, unsecured promissory notes, only firms with a high credit rating are eligible to issue them.

The liquidity crisis in the financial sector following the banking crisis of 1997, coupled with Government-initiated reforms, forced firms to adopt a downsizing strategy. In contrast to Samsung and LG groups, who sold off some affiliates, the chairman of Daewoo (and Hyundai) wanted to maintain/expand his business empire (I,e. long-term 
projects) by rolling over the loans. ${ }^{10}$ The non-pecuniary benefits obtained by managers can make them reluctant to liquidate a corporation even when it is socially optimal to do so (Grossman and Hart, 1982; Aghion and Bolton, 1992). The long-lasted belief of toobig-to fail might have misled some chairmen's judgements in critical situations. Rolling over short-term finance and bank-guaranteed corporate bonds was the financing strategy of the financially distressed chaebols. At first, the domestic creditor banks tried to rescue existing debts of sixty trillion won through roll-over; they also provided four trillion won in new loans (Krause, 2000). However, the banks (and the Government) realised that such a simple refinancing strategy was inadequate to rescue the troubled Daewoo.

\subsection{Corporate Financing}

The major source of corporate financing has changed since the onset of the 1997 financial crisis. Whereas indirect financing dominated until the onset of the 1997 crisis (Figure 1: left panel), direct financing (stock and long-term bonds) took over the top position after 1999, although the relative importance of these two sources remained almost the same until 2005.

While the importance of the stock market has continuously increased over the last three decades, the corporate long-term bond market has experienced significant changes (see Figure 1: right panel). The growth of the stock market was led by the V-shaped recovery of economic growth from the crisis and the increased participation of foreign investors following the deregulation of foreign ownership. Government regulations to restrict debt finance also led firms to rely more on the stock market.

The bond market grew significantly in value terms until the collapse of the Daewoo group in 1999. The ratio of outstanding value to GDP increased from $13.3 \%$ in 1990 to $16.1 \%$ in 1995 and $23 \%$ in 2000 . This ratio is comparable with the U.S. and Japan. ${ }^{11}$ Korea has the most active and sophisticated corporate bond markets in Asia, and its asset backed securities (ABS) market in particular is a leader in the Asian ABS market (Rhee et al., 2003). The reasons for this include the absence of bond issuance control, ${ }^{12}$ the conservative loan behaviour of banks; and Government regulation of corporate debt-equity ratios.

10 Incidentally, the director of the Financial Supervisory Committee which initiated corporate restructurings following the onset of the crisis was a close friend of Daewoo chairman's friends. There are some similarities between the Daewoo and the Hyandai groups, as both increased their debts during 1998. Hyundai purchased LG's semiconductor business in the process of the 'big-deal' and also expanded its non-profitable tourist business in North Korea where its chairman was born.

In contrast, Otsubo, the director of Japan's Matsushita electronics company, argues that Samsung has excellent adaptability to the changing market environment and made quality decisions to invest in equipment and public relations ("Hankook Daily Economy", 31 July, /2006, cited in Nikkei Business).

11 However, the relative importance of corporate bonds in the bond market declined from 53\% in 2003 to around $30 \%$ in 2005 due to the rapid increase in the number of government bonds. In contrast to its long history in the U.S. and Japan, the Government bond market in Korea has only begun to grow since the 1997 crisis. Due to public injection of funds in the banking sector and social network expenditure, the Government bond market increased sharply. The share of Government bonds in the bonds market has increased significantly, from $17 \%$ in 2000 to $35 \%$ in 2005 . Three-year maturity Government bonds have replaced corporate bonds as the benchmark.

12 The Government lifted the upper limits on the issuance of corporate bonds in December 1997 to help resolve the corporate liquidity crisis following the currency crisis. 
FIGURE 1

\section{CHANGES IN CORPORATE FINANCE IN KOREA (UNIT, BILLION WON)}
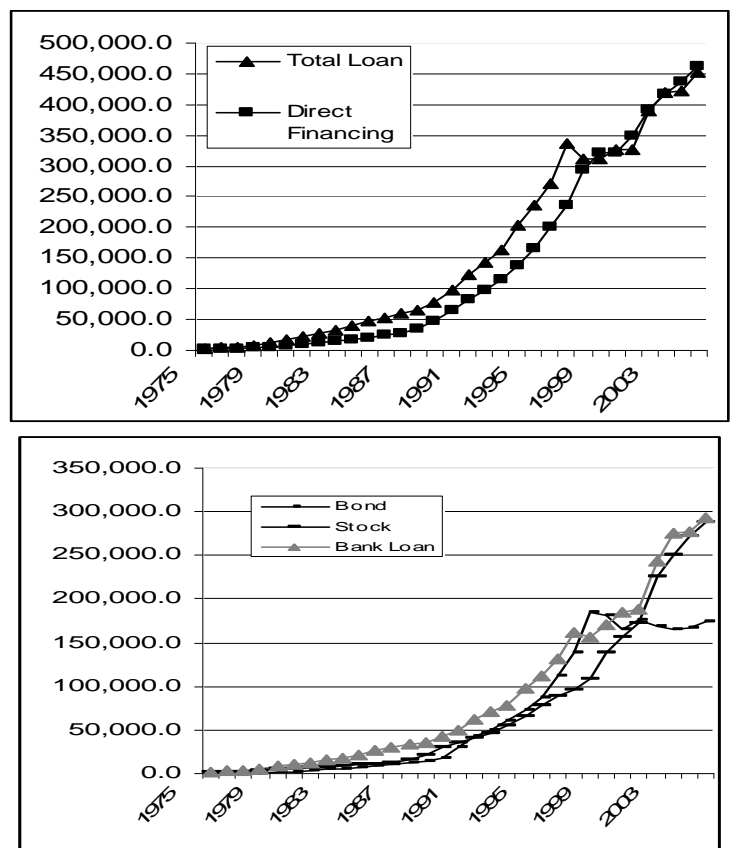

Notes: 1. 'Total loan' includes loans from commercial banks, the Bank of Korea, insurance companies, merchant banks, credit specialised institutions, and others.

2. Direct financing includes long-term corporate bonds and stocks.

3. Bank loans refer to loans from commercial banks.

Data source: The Bank of Korea's Flow of Funds Accounts.

\subsubsection{Capital Market and Corporate Governance}

The threat that a corporate raider may attack poorly performing management enhances the M-mode governance mechanism. This mechanism assumes an active take-over and M\&A environment in the share market (Cremers and Nair, 2005). Take-over and (hostile) M\&A activities were not popular in Korea, due in part to a prohibition on hostile M\&As. Hostile M\&As only occurred after the crisis. In May 1998, foreign ownership restrictions were completely lifted except in the case of some public enterprises. $^{13}$

The issuing of payment guaranteed bonds has ceased. Prior to the crisis, bonds were a 'saving vehicle' with higher interest rates, as payment was guaranteed by financial institutions including the banks. The banks guaranteed corporate bonds and held them to maturity, implying an alternative method to roll-over loans to a specific company when banks faced loan exposure regulation (Rhee et al., 2003). Bond holding was classified as portfolio investment. However, virtually all corporate bonds have become nonguaranteed since the crisis because the banks (and investment trust companies) could no longer afford to provide guarantees to the bond issuers. The banks have become extreme

13 The limit is $3 \%$ for individual foreign investors and $40 \%$ for foreign investors as a whole. 
risk averters due to NPLs and BIS 8\% regulations. Investors need to consider default risks, and the issue of designing a corporate governance system via bond indenture becomes important. In particular, creditors' decision not to continue the loans to the Daewoo group in July 1999 had important implications for the relationship between the banks and the top chaebols. The myth of 'too-big-to-fail' was disproved, and this made investors extremely risk averse. This changed investor attitude, combined with the introduction of the market-to-market system, means that only very high quality bonds can currently be issued. Consequently, the ability of the capital market's corporate governance mechanism to ensure the borrower's choice of quality projects has recently become an issue.

\subsection{Medium to Small Business Groups}

The role of the banks in controlling financially distressed corporations became crucial after the crisis because of the implementation of corporate restructuring, particularly of the top six-to-thirty chaebols. Leverage had increased more quickly for the these top chaebols up to the onset of the crisis, compared to the top five chaebols and nonchaebol corporations (Lee and Lee, 1998). The top five chaebols were heavily regulated in terms of bank financing. On the other hand, the medium-to-small chaebols had better access to credit using the mutual debt payment system. Part of their advantage derived from the fact that many of the top six-to-thirty chaebols owned NBFIs, whereby they could channel funds to the group. ${ }^{14}$

During the crisis, banks could be involved in corporate governance as creditors, as outside directors, or as outside auditors. At the same time, the banks' corporate governance power was restricted because of their vulnerable financial structure. The Korean banks preferred short-term financial products including $\mathrm{CP}$ to long-term products. This is because of the prolonged interest difference between banking under government controls and NBFIs in the process of interest rate deregulation that began in 1991. The banks sought more profitable CP to compensate them for high costs through the trust accounts.

While the banks played a crucial role in restructuring financially distressed chaebols, the huge number of NPLs resulting from the failure of many firms adversely affected the their financial structure. The bankruptcies of medium-to-large chaebols increased the total NPLs in savings banks (refer to Footnote 9). ${ }^{15}$ The subsequent capital injection of 86 trillion won into the banking sector made the commercial banks virtually public companies. Furthermore, restructuring in the banking sector increased uncertainty and the banks were obliged to maintain a BIS capital equity ratio of $8 \%$. The bank could no longer regard loan to chaebols per se as a safe business.

\subsection{Medium and Small-Sized Firms}

The pattern of corporate finance by small and medium-sized enterprises (SMEs) for capital-equipment investment has changed significantly since 1997 (see Table1).

14 At the end of 1997, there were 487 NBFIs including merchant banks (29), securities (26), investment trusts (24) and life insurance (13). The share of the top six-to-thirty chaebols in NBFIs was approximately $10 \%$ whereas the share of the top five chaebols was around $5 \%$.

15 Corporations that went bankrupt or into court receivership in 1997 included Hanbo steel, Sammi, Jinro, Daenong, Hanshin Construction, Kia Auto, Kia Steel, Saangbang-Wool, Haitai and Halla Construction. 
TABLE 1

THE CHANGING PATTERN OF SMES' FINANCE FOR CAPITAL-EQUIPMENT INVESTMENT (\%)

\begin{tabular}{lrrr}
\hline & 1997 & 2000 & 2003 \\
\hline Internal Finance & 59.7 & 77.9 & 80.5 \\
External Finance & & & \\
$\quad$ Loans & 23.7 & 13.9 & 15.4 \\
$\quad$ Policy loans & 10.3 & 5.1 & 3.6 \\
$\quad$ Corporate bond, share & 0.3 & 0.0 & 0.0 \\
$\quad$ Others (foreign loans, etc.) & 5.1 & 3.1 & 0.5 \\
\hline
\end{tabular}

Note: SME is defined as a firm employing less than 300 workers.

Source: The Korean Federation of Small Businesses, Report on Small Businesses Survey, various issues.

The share of internal finance by SMEs' finance for capital-equipment investment has increased from $59.7 \%$ in 1997 to $77.9 \%$ in 2000 and further to $80.5 \%$ in 2003 . There are two important reasons for this increase. First, SMEs have been forced to rely on internal finance due to limited accessibility to external finance. The lenders including banks who are required to meet a BIS $8 \%$ equity ratio regulations have become extremely cautious to provide funds to the risky SMEs. Second, the Korean Government has implemented policies that aim to reduce the SMEs' debt-equity ratio. The Government was concerned about how to reduce a vulnerable financial structure in the economy, particularly following the 1997 crisis.

This increased internal finance has contributed to the decline of debt-equity ratio. The ratio dropped from $394.9 \%$ in 1980 to $138.7 \%$ in 2004 . This debt-equity ratio of $138.7 \%$ in Korea was lower than Japan's $(240.8 \%)$ but was higher than that of the US $(114.2 \%)$ in 2004 . This decreased debt-equity ratio, coupled with lowered interest rates, lessened the SMEs' burden of interest-costs. Thus the ratio of interest payment to sales revenue declined from $4.4 \%$ in 1990 to $2.9 \%$ in 2000 and to $1.5 \%$ in 2004 .

In contrast to the increased internal finance, SMEs' external finance has shrunk since the crisis. The shares of all sources of external finance including loans from financial institutions, policy loans, securities from the capital market, and foreign loans for capital-equipment investment has decreased. In particular, the reputed chaebols' domination has heavily crowded out SMEs from the corporate bond markets.

There are two important policy implications of this decreased external finance. First, it has led to a withered investment in capital equipment and machinery with some lagged effects. The planned investment from SMEs has declined rapidly since 2002, whereas the investment from large firms has picked up since 2001 (Korea Development Bank, Research on Planned Equipment Investment, various issues). Second, the difficulty of external finance, combined with soaring wage, pushed SMEs to relocate production facilities abroad, including China and Southeast Asia. The overseas investment from SMEs has risen from 640 million US dollars in 1995 to 2,330 million in 2000 , followed by a drop somewhat to 1,460 million in 2003 and 2,220 million in 2004 . 


\section{Is the M-mode of Governance a Panacea?}

The type of financial system that can provide a way to deal with asymmetric information and incentive problems generally changes over time and differs across geopolitical subdivisions. The R (relationship)-mode system and the M (market)-mode system both have advantages and disadvantages. The need for corporate governance should also be understood from a dynamic perspective, given different cultural backgrounds and legal systems. The following section analyses some critical issues for improving external corporate governance to enhance corporate performance, given the contractual situation following the crisis.

\subsection{The Equity Market, Foreign Ownership and Corporate Raiders}

The effectiveness of the M-mode governance system has yet to be proven, for the following reasons. First, a large proportion of the affiliates of chaebols are still unlisted. The average listed ratio of the top forty-one business groups' affiliates is approximately $50 \%$ as of April 2006 (Fair Trade Commission, 2006). ${ }^{16}$ This ratio ranged from $32.93 \%$ (Lotte) to $92.5 \%$ (Hanjin Heavy Industry). The publicly stated ratios of the top business groups (apart from Hyundai's 92.4\%) are also relatively low: Samsung (41.1\%), LG (84.6\%), Hyundai Motor Vehicles (70.0\%) and SK (53.1\%).

Second, there is a huge disparity between a chairman's (and family) levels of ownership and managerial control (share of voting rights). This is because of the existence of interlocking shareholdings among affiliates. The disparity in the top fortyone chaebols (which are subject to restrictions on mutual interlocking shareholdings) in April 2006 was $30.6 \%$ and the ratio of voting rights to ownership was 6.71:1 (Fair Trade Commission, 2006). These figures showed little change from the previous year. This system of interlocking shareholdings is an effective bar to M\&As. Given such circulatory interlocking shareholdings among affiliates, the threat of M\&As can worsen corporate governance rather than improving it. The chairperson of a group can strengthen his managerial control by raising circulatory interlocking shareholdings to defend themselves from threat even when corporate performance is poor. ${ }^{17}$ La Porta et al. (1999) examined twenty-seven developed economies and found evidence of 'tunnelling' whereby controlling shareholders exploited their power at the expense of other shareholders if managerial power exceeded ownership through an interlocking/pyramid ownership structure.

Third, as a result of deregulation, the foreign share of purchases increased from $6 \%$ in 1996 to $18 \%$ ( $40 \%$ in market value) at the end of 2003 . Around $5 \%$ of listed companies had (aggregated) foreigners as the largest shareholders. ${ }^{18}$ The increased

16 These top forty-one chaebols have common characteristics that include: (1) the size of their assets is over two trillion won; (2) a chairman that is the focal point of control; and (3) the prohibition of (direct) mutual shareholding.

17 Hankyoreh (Daily Newspaper) reported (17 July, 2006) that Hyundai (HD) Elevator, as the de facto holding company, had recently achieved circulatory interlocking shareholdings with other subsidiaries of the group. Following the trading of shares among affiliates, HD Elevator owned $18.72 \%$ of shares in HD Marines, which in turn owned $48.78 \%$ of shares in HD Delivery Co, which in turn owned $12.27 \%$ of shares in HD Elevator Co. This increase in circulatory interlocking shareholdings may be helpful in defending managerial control against hostile M\&As. However, this is a counter-measure against the current corporate governance structure that was introduced after the crisis.

18 Foreign investors prefer blue-chip companies including Posco (66.7\%), Hyundai Industry Development $(59.8 \%)$ and Samsung Electronics (57.3\%). Note that this high 'aggregated' foreign ownership does not 
share of foreign investors contributes to increased market transparency. It may also improve some aspects of corporate governance, as witnessed in the Sovereign- SK conflict in 2003 (Kim, 2004). However, there has been some debate about whether or not the behaviour of foreign investors exhibits 'herding' (Choe, Kho and Stulz., 1999; Kim and Wei, 1999). If shared information about the fundamental value of a share affects a fund manager's behaviour, the probability of 'herding' may increase, along with the development of information technology.

Fourth, Koreans are influenced by Asian Confucianism and tend to regard hostile M\&As as an ideal rather than a reality. The Asian culture tends towards private resolutions rather than court proceedings and take-overs in the market (Hoecklin, 1995; Hofstede, 1984). Korean commercial law has a system similar to that of Germany and Japan, whereby private resolutions are preferred to court resolutions.

\subsection{Bond Markets and Information Disclosure}

A major function of credit rating agencies is to prevent market failure caused by asymmetric information between investors and bond issuers. Despite its growth in quantity terms, the corporate bond market has been volatile and until recently has exhibited a low level of information disclosure (Joo and Pruitt, 2006). A survey from fund managers shows that credit ratings are an important source of information for the transaction of bonds, but that they have low credibility (Lim, 2004). Approximately $62 \%$ of respondents in Korea expressed a negative opinion of credit ratings, whereas the US institutional investment agencies showed a $35 \%$ rate.

Moreover, there could be a conflict of interest among stakeholders. First, let us take the case of the Government-owned specialised bank, the Korea Development Bank (KDB). As a main shareholder in credit rating agencies, the KDB has significantly increased its market share in the bond market as a result of its involvement to moderate the boom- bust cycle in the bond market, which has accelerated since July 1999 when Daewoo collapsed. ${ }^{19}$ Second, credit rating agencies may want to avoid deterioration of their relations with existing customers, especially those with affiliations to business groups. Poor relations with an affiliate may create a negative externality in relation to the group as a whole.

\subsection{R-mode Corporate Governance}

The big-name chaebols have dominated both the domestic bond market and international debt markets. As Diamond's (1991) reputation model indicates, these business groups have experienced disintermediation in corporate finance, whereby the effectiveness of the R-mode may be diminished. Government regulation of the debtequity ratio limit of $200 \%$ also facilitated this direct financing.

Unlike the direct Government-instigated restructuring of the top five chaebols, creditors initiated workouts (corporate improvement plans without bankruptcy law) for

directly imply managerial control. Many Korean chairmen are still the largest 'individual' shareholders of a core company in their group.

19 KDB's market share increased from $2.8 \%$ in 1999 to $17.6 \%$ in 2001 , before falling to $8.7 \%$ in 2002 , and increasing again to $17.1 \%$ in 2004 . 
the top six to sixty-four business groups in Korea. ${ }^{20}$ The role of the banks was crucial to restructuring the indebted top six-to-thirty chaebols via these workouts following the crisis. A Corporate Restructuring Coordination Committee has been formed to mediate disputes between borrowers and lending institutions, and can implement solutions in case of a deadlock. The banks can make decisions about roll-overs through renegotiation with debtors. As of mid-1999, ninety affiliates of seventeen chaebols were subject to these workouts, including debt- equity swaps and interest subsidies. The syndicated loan committee classified fifty-five affiliates as unsustainable and to be liquidated. ${ }^{21}$ Banks introduced a loan review system to increase selectivity between viable and non-viable firms. This could increase the banks' monitoring power over SMEs.

However, the workouts seem to have failed for two reasons. First, the banks charged higher than market interest rates to compensate them for the risk of default. This created a financial burden on the financially distressed firms. The progress of the financially distressed firms' self-rescue plans including their disposal of assets was less than $50 \%$ of the planned extent. Only $25 \%$ of 112 expected sales of affiliates were successful. Second, according to Nam (1999), the debt- equity swap was only around four trillion won. Similar to the American Bank's debt- equity swap transaction in response to Latin America's credit problems in the mid 1980s, the Korean Government encouraged the banks to make the swap for the medium to small chaebols' credit with equity. A bank lender considering such a swap transaction should compare it to other relevant alternatives such as the sale of the loan, or trading the loan to another bank for a different loan (Grosse, 1992). The basic transaction involved in a debt- equity swap is the conversion of a bank loan into an equity investment in the borrowing firm. The economic function of this transaction is to offer the creditor an opportunity to replace the fixed-income debt instrument with a variable-income equity one. Having noted the increased uncertainty about the borrowers' cash flows, the Korean banks have had little incentive to undertake such swap transactions.

A dual demand for bank loans has existed since the crisis. The regulation limiting debt-equity ratios to $200 \%$ and prohibition of mutual payments among affiliates drove the chaebols to rely more on the bond market. And because investors became extreme risk averters due to the collapse of Daewoo, only big-name firms (those with a credit rating of $\mathrm{A}^{+}$and above) can issue bonds. In contrast, SMEs with a poor reputation have continued to depend on bank loans.

An empirical study by Choe and Moosa (1999) implied that sound development of financial intermediaries is crucial for economic growth in Korea. Competition among potential financiers is a two-edged sword (Rajan, 1992). On the one hand, the inside bank's ability to appropriate surplus is reduced, which improves the manager's incentive to exert effort. On the other hand, the bank's control over the project is also reduced because uninformed creditors may continue a negative net-present-value

20 The Korean Government assisted small and medium independent firms by: (1) requiring banks to rollover small and medium sized firms' debt for six months (and extend this for another six months); (2) creating a credit insurance fund; (3) providing a central bank credit line; and (4) providing funding for trade finance.

21 These fifty-five companies include twenty affiliates of the top five chaebols (Hyundai 4, Samsung 4, Daewoo 5, LG 4, and SK 3); twenty-one recipients of syndicated loans; and fourteen others. 
project. First, the foreign banks' market share increased from $10.6 \%$ in 1996 to $20 \%$ in 2001 , and stood at approximately $27 \%$ at the end of 2003 . Furthermore, around $60 \%$ of shares in domestic commercial banks (apart from Government-owned specialised banks) in October 2005 were owned by foreign investors. Korean law prohibits industry from owning more than $10 \%$ of bank shares, and voting rights are restricted to no more than $4 \%$. Foreign banks introduced advanced financial techniques and capital injection during the liquidity crisis. Currently, however, profit-maximising behaviour has eroded the public good will towards the banks. Industry loans, particularly to SMEs, have shrunk. Influenced by the strategies of foreign banks, domestic banks have increased their home loans at the expense of industry loans. Harris et al. (1994) have shown that the shift towards the M-mode allocation of credit has increased borrowing costs, particularly for smaller firms in Indonesia. In line with this finding, the share of loans to SMEs in Korea fell from $40.2 \%$ in 2000 to $34.6 \%$ in 2004 . The share of mining and manufacturing in total loans and discounts of commercial and specialised banks declined from $24.8 \%$ in 2001 to $19.8 \%$ in 2005.

Second, the financial restructuring following the crisis resulted in a larger but more concentrated banking system. Through M\&As, the number of banks (city and local) declined dramatically from twenty-seven in 1997 to eleven in 2005. In theory, a concentrated financial system with many small banks imposes tighter budget constraints than a concentrated system with a small number of banks (Dewatripont and Maskin, 1995). This implies that debtors are encouraged to take on long-term projects under a concentrated system to a greater extent than would be the case under a fragmented financial system. Huang and Xu (1999) show that an economy dominated by imitative industries with a low degree of uncertainty is closely correlated with a concentrated bank system. However, it is still uncertain whether or not the more concentrated banking system in Korea since the crisis will affect the investment pattern.

\section{Summary and Conclusion}

By analogy with property theory, we classify financial contracts as either relationshipbased (R-mode) or market-oriented (M-mode) contracts. This paper has analysed: (1) the dynamic relationship between business groups and the banks before and after the crisis; and (2) factors to be considered to enhance external corporate governance with a view to improving corporate performance, given differences in cultural backgrounds and legal systems.

Before the crisis, crony capitalism weakened creditors' corporate monitoring, and led to a prolonged period of excessive inefficient investment. The 'big-push' industry growth policy in the 1970s using debt financing, combined with unsatisfactory corporate governance by creditors and ownership protection, contributed to the creation of business conglomerates, which in turn had a huge impact on the economy-both positive and negative. The chaebol affiliates of had greater access to the credit market through mutual payment guarantees than did the non-affiliates. In many cases the chairmen's level of control greatly exceeded their level of ownership due to circulatory interlocking shareholdings among affiliates. Although these factors may have helped to overcome coordination failures in the early stages of development, the legacies of poor corporate governance snow-balled.

Following the crisis, changes in corporate financing, coupled with the introduction of Anglo-American style internal governance elements (including requirements for outside board members and strengthening of the rights of minority shareholders) shifted 
the weight of the governance system more towards the M-mode. However, the effectiveness of M-mode governance in improving corporate performance has yet to be found, partly due to: (1) the low average listed ratios of the top forty-one business groups' affiliates; (2) the large disparity between levels of ownership and managerial control; (3) the myopic business strategies of foreign investors; (4) the absence of quality information disclosure in the bond market; and (5) deep-rooted cultural factors and the civil law system.

Unlike the disintermediation of the big-name firms, the affiliates of small and medium business groups and independent firms have relied heavily on bank loans and internal finance. Despite improved bargaining power, however, the banks' credit allocations to industry have declined. This is due to intensified competition with foreign banks and the intention to reduce default risk. The impact of a more concentrated banking system on the Korean type of corporate investment has yet to be analysed.

\section{REFERENCES}

Aghion, P. and Bolton, P. (1992) "An Incomplete Contracts Approach to Financial Contracting", Review of Economic Studies, 59, pp.:473-494.

Black, B., Cheffins, B. and Kausner, M. (2003) "Outside Director Liability": Paper presented at the 2003 Korea Development Institute (KDI) conference on corporate governance and capital market in Korea, 15-17 December, Seoul.

Borensztein, E. and Lee, J-W. (1999) "Credit Allocation and Financial Crisis in Korea", IMF Working Paper No. 20.

Business Week (2004) "Hyundai Gets Hailed in Auto Quality", 28 April, 2004.

Chiu, M. M. and Joh, S. W. (2003) "Bank Loans to Distressed Firms: Cronyism, Bank Governance and Economic Crisis, Korea University", unpublished mimeographed document.

Choe, H. and Lee, B. S. (2003) "Korean Bank Governance Reform after the Asian Financial Crisis", Pacific Basin Finance Journal, 11, pp. 483-508.

Choe, H. Kho, B-C., and Stulz, R. (1999). "Do Foreign Investors Destabilise Stock Markets? The Korean Experience in 1997”, Journal of Financial Economics, 54, pp. 227-264.

Choe, C., and Moosa, I. A. (1999) "Financial System and Economic Growth: The Korean Experience", World Development, 27, pp. 1069-1082.

Claessens, S. (2003) "Origin of Corporate Distress in East Asia": Paper presented at the KDI conference on Empirical Evaluation of Corporate Restructuring in Northeast Asia, 12 November, Seoul.

Claessens, S., Djankov, S., Fan, J. P. H. and Lang, L. H. P. (2002) "Disentangling the Incentive and Entrenchment Effects of Large Shareholdings", Journal of Finance, 57, pp. 2741-2772.

Corsetti, G., Pesenti, P., and Roubini, N. (1999) "Paper Tigers? A Model of the Asian Crisis", European Economic Review, 43, pp. 1211-1236.

Cremers, K. J. and Nair, V. B. (2005) "Governance Mechanisms and Equity Prices", Journal of Finance, 60, pp.:2859-2894.

Denis, D. K. and McConnell, J .J. (2003) "International Corporate Governance", Journal of Financial and Quantitative Analysis, 38, pp.:1-36.

Dewatripont, M. and Maskin, E. (1995) "Credit Efficiency in Centralised and Decentralised Economies”, Review of Economics Studies, 62, pp. 541-555. 
Diamond, D. (1991) "Monitoring and Reputation: The Choice between Bank Loans and Directly Placed Debt, Journal of Political Economy, 99, pp. 688-721.

Fair Trade Commission (2006) "Information on the Largest Business Groups' Ownership Structure 2006” (Seoul: Fair Trade Commission, Media Report Materia).

Fee, C. E., Hadlock, C. J. and Thomas, S. (2006) "Corporate Equity Ownership and the Governance of Product Market Relationships”, Journal of Finance, 61, pp. 1217 1251.

Fortune (2005) “The World's Most Admired Companies”, 3 July, 2005.

Graham, E. (2003) Reforming Korea's Industrial Conglomerates (Washinggton D.C.: Institute for International Economics).

Grosse, R. (1992) “The Debt/Equity Swap in Latin America-In Whose Interest?", Journal of International Financial Management and Accounting, 4, pp. 13-39.

Grossman, S. and Hart, O. (1982) "Corporate fFnancial Structure and Managerial Incentives" in McCall, J. (ed.), The Economics of Information and Uncertainty (Chicago: University of Chicago Press), pp. 107-137.

Haggard, S., Lim., W and Kim, E. (2003) Economic Crisis and Corporate Restructuring in Korea: Reforming the Chaebol (Cambridge: Cambridge University Press).

Harris, J. R., Schiantarelli, F. and Siregar, M. G. (1994) "The Effects of Financial Liberalisation on the Capital Structure and Investment Decisions of Indonesian Manufacturing Establishments", World Bank Economic Review, 8, pp. 17-47.

He, D. (2004) "The Role of KAMCO in Resolving Non-performing Loans in the Republic of Korea", IMF Working Paper, No. 04/172.

Himmelberg, C. P., Hubbard, R. G. and Palia, D. N. (1999) "Understanding the Determinants of Managerial Ownership and the ILnk between Ownership and Performance", National Bureau of Economic Research Working Paper, No. 7209.

Hoecklin, L. (1995) Managing Cultural Differences: Strategies for Competitive Advantage (Wokingham: Addison-Wesley Publishing).

Hofstede, G. (1984) Culture's Consequences: International Differences in WorkRelated Values (Beverley Hills: Sage Publications).

Huang, H., and Xu, C. (1999) "Institutions, Innovations, and Growth", American Economic Review, 89, pp. 438-443.

Huddart, S. (1993) "The Effect of a Large Shareholder on Corporate Value", Management Science, 39, pp. 1407- 1421.

Imbs, J. (2006) "The Real Effects of Financial Integration", Journal of International Economics, 68, pp. 296-324.

Ji, D., and Park, J. (1999) The Korean Banking Sector: Current Issues and Future Direction, in Rising to the Challenge in Asia: A Study of Financial Markets (Manilla: Asian Development Bank), pp. 27-54.

Joh, S. W. (2003) "Corporate Governance and Firm Profitability: Evidence from Korea before the Economic Crisis", Journal of Financial Economics, 68, pp. 287- 322.

Joh, S. W. (2001) "The Korean Corporate Sector: Crisis and Reform" in Kwon, Y. and Shepherd, W. (eds), Korea's Economic Prospects: from Financial Crisis to Prosperity (Cheltenham: Edward Elgar), pp. 116-139.

Johnson, S., Boone, P., Breach, A. and Friedman, E. (2000) "Corporate Governance in the Asian Financial Crisis”, Journal of Financial Economics, 58, pp. 141- 186.

Johnson, S., La Porta, R., Lopez-de-Silanes, F. and Shleifer, A. (2000) “Tunneling”, American Economic Review, 90, pp. 22-27. 
Joo, S. L. and Pruitt, W. (2006) "Corporate Bond Ratings Changes and Economic Instability: Evidence from the Korean Financial Crisis”, Economics Letters, 90, pp. $12-20$.

Kaminsky, G. L. and Reinhart, C. M. (1999) "The Twin Crises: The Causes of Banking and Balance-of-Payments Problems", American Economic Review, 89, pp. 473-500.

Kim, W. C. and Wei, S-J. (1999) "Foreign Portfolio Investors Before and During a Crisis, NBER Working Paper, No. 6968.

Kim, Y. Y. (2004) Challenges and Current Status of M\&A (Seoul: Korea Institute for Industrial Economics and Trade).

Krause, L B. (2000) "The Aftermath of the Asian Financial Crisis for South Korea", Journal of the Korean Economy, 1, pp. 1-23.

Kyle, A. S. and Xiong, W. (2001) "Contagion as a Wealth Effect", Journal of Finance, 56, pp. 1401-1440.

La Porta, R., Lopez De Silanies, F. and Shleifer, A. (1999) "Corporate Ownership Around the World", Journal of Finance, 54, pp. 471-517.

La Porta, R., Lopez De Silanies, F., Shleifer, A. and Vishny, R. W. (1998) "Law and Finance", Journal of Political Economy, 106, pp. 1113-1155.

Lang, L. H. P. and Stulz, R. M. (1994) “Tobin's q, Corporate Diversification, and Firm Performance", Journal of Political Economy, 102, pp. 1248- 1280.

Lee, J. W. and Lee, Y-S. (1998) "Capital Structure of Korean Firms: Comparison of Chaebol Firms and Non-chaebol Firms 1981-1996", Paper presented at the Korean Meeting of the Econometric Society, Seoul.

Lee, Y. K. (1996) Corporate Governance (Seoul: Development Institute), pp. 112-115.

Lim, Y. (2003) "The Corporate Bankruptcy System and the Economic Crisis" in Haggard, S., Lim., W. and Kim, E. (eds), Economic Crisis and Corporate Restructuring in Korea: Reforming the Chaebol (Cambridge: Cambridge University Press).

Lim, K. M. (2004) Policy Options to Improve Credit Rating Functions in Corporate Bond Market (Seoul: Korea Development Institute, Policy Research Series No. 2004-04).

Lins, K. V. (2003) "Equity Ownership and Firm Value in Emerging Markets", Journal of Financial and Quantitative Analysis, 38, pp. 159- 184.

Mitton, T. (2002) "A Cross-Firm Analysis of the Impact of Corporate Governance in the East Asian Financial Crisis, Journal of Financial Economics, 64, pp. 215-241.

Min, B. S. (1999) "Impact of the Financial Crisis on Bank-Big Business Group Relationships in Korea: Some Corporate Governance Context", Economic Papers, 18, pp. 59-72.

Nam, I. C. and Oh, S. (2000) Bankruptcy of Large Firms and Exit Mechanisms in Korea, Research Monograph 2000-2001 (Seoul: Korea Development Institute).

Nam, S. W. (1999) "Korea's Economic Crisis and Corporate Governance", (Seoul: Korea Development Institute), unpublished mimeographed document.

Nam, S. W. (1996) "The Principal Transactions Bank Systems in Korea and a Search for a New Bank-Business Relationship" in Ito, T. and Krueger, A. O. (eds), Financial Deregulation and Integration in East Asia (Chicago: National Bureau of Economic Research, The University of Chicago Press).

National Federation of Economists (1996) Tasks for Deregulation of 100 Core Areas (Seoul: National Federation of Economists). 
Park, K. S. (1997) A Study on the Bank's Ownership and Governance Structure (Seoul: Korea Institute of Finance).

Ra, S. and Yan, G. (2000) "Bad Credit Equilibria with the Abnormally Utilised Commercial Paper: A Catalyst of the Korean Currency Crisis", Journal of the Korean Economy, 1, pp. 325- 352.

Rajan, R. G. and Zingales, L. (2000) “The Governance of the New Enterprise" in Vives, X. (ed.), Corporate Goverance (New York: Cambridge University Press).

Rhee C., Shin, S. and Yoon, Y. (2003) "Designing the Governance Structure of Corporate Bonds in Korea: Empirical Study on Corporate Bond Indentures in Korea”, Paper presented at the 2003 Korea Development Institute (KDI) Conference on Corporate Governance and the Capital Market in Korea, December 15-17, Seoul.

Shin, H. and Park, Y. S. (1999) Financing Constraints and Internal Capital Markets: Evidence from Korean Chaebols", Journal of Corporate Finance, 5, pp. 169-191.

Shleifer, A. and Vishny, R. (1997) A Survey of Corporate Governance, Journal of Finance, 52, pp. 1131- 1150.

Sundararajan, V. (1985) "Debt- Equity Ratios of Firms and Interest Rate Policy", IMF Staff Papers, 32, pp. 430- 474.

Villalonga, B. and Amit, R. (2006) "How do Family Ownership, Control and Management Affect Firm Value?", Journal of Financial Economics, 80, pp. 385417.

Yoo, S-M. (1999) Corporate Restructuring in Korea: Policy Issues Before and During the Crisis (Seoul: Korea Development Institute). 